\title{
CORIRESOINDEINCE.
}

\section{HEIGHTS OF CHALK.}

Sir,-I am glad that Mr. Lamplugh has corrected me as to the greatest beight of the northern Chalk. Garrowby Hill seems to lie near the edge of the elevated area; in going over the sheets of the Ordnance Map I had not noticed its exceptional height; 1 have never been in that part of the district.

Besides this correction another has to be made. I wrote: "Mr. Deeley tells us that Chalk-drift is found in Leicestershire up to 800 feet." But his actual words are: " "At Tilton, one of the highest points in East Leicestershire"; he makes no definite statement of heirht. The ground at Tilton rises to 700 feet; the figures 800 are a slip of my own memory. So I have not only made an incorrect statement, but made Mr. Deeley seem responsible for it.

January $24 t h, 1896$.

E. Hrit.

\section{ON THE APPENDAGES OF TRILOBITES.}

Sin,-At the present time, when the important researches on the structure of Trilobites, recorded of late years, have highly excited the interest of palæontolugists upon this subject, I hope you will permit me to call attention to an observation on the antennæ of these fossils made by Linnæus upwards a hundred and forty years ago, and, as far as I know, never referred to. In the Proceedings of the Swedish Academy of Science ("Svenska Vetenskaps-academiens Handlingar"), vol. xx, issued in 1759, Linnæus communicated an article entitled "Petrificatet Entomolithus paradoxus, sådant, som det finnes uti Hans Excellence Riks-Rådets Högoälborne Herr Grefve C. G. Tessins Samling." A specimen of Parabolina spinulosa, Wablenb., is there figured, tab. i, fig. 1, showing one pair of antenna at their true place; and from the accompanying description it appears that the anthor attached due importance to the presence of these organs. His words relative to them (pp. 21, 22) run thus, translated into English: "Fig. 1 is one of the clearest specimens I ever saw among so many thousands. Most remarkable in this specimen are the antennæ in the front, which I never saw in any other example, and which clearly prove this fossil to belong to the insects" (=Arthropoda). The specimen in question had been found by Dr. Tidström, and was shown to Linnæus, as seen above, by the Count C. G. Tessin. This reference to an old observation can by no means abate anything of the value of the brilliant discoveries of our days, but justice demands this discovery of Linnæus to be rescued from the oblivion into which it seems to have sunk.

Sv. Leonk. Törneuist.

Lund (Swedex), February, 1896.

1 Quart. Journ. Geol. Soc., vol. xlii, p. 463. 